Crop Breeding and Applied Biotechnology 15: 258-264, 2015

Brazilian Society of Plant Breeding. Printed in Brazil

\title{
ARTICLE
}

http://dx.doi.org/10.1590/1984-70332015v15n4a43

\section{Evaluation of combining ability in white corn for special use as corn grits}

Lucas Souto Bignotto ${ }^{1}$, Carlos Alberto Scapim ${ }^{1}$, Ronald José Barth Pinto ${ }^{1}$, Lucas Rafael de Souza Camacho ${ }^{1 *}$, Mauricio Carlos Kuki ${ }^{1}$ and Antonio Teixeira do Amaral Júnior ${ }^{2}$

Received 11 November 2014

Accepted 15 January 2015

\begin{abstract}
To assess the genetic potential of white corn for corn grits, 28 hybrids resulting from diallel crosses of eight parents, including parents and $S_{1}$ generations, were evaluated. The combining abilities and levels of heterosis and inbreeding depression were estimated. The parents used were the main white maize hybrids of the Brazilian germplasm. The combinations HT $9332 \times$ HT 392, IAC Nelore x HT 9332, IAC Nelore x HT 932, and IPR $119 x$ IAC Nelore are promising for reciprocal recurrent selection programs targeting higher grain yield. Hybrid IPR 127 was indicated as a source of industrial lines with favorable traits for dry-rolled corn production. Hybrid IAC Nelore had the lowest estimate of inbreeding depression and was recommended for the breeding of lines and participation in higher-yielding hybrids and composites.
\end{abstract}

Key words: Zea mays $L$., heterosis, grit production.

\section{INTRODUCTION}

The transformation of maize in different derivatives allows the use of cereals as raw material for multiple applications in the food industry. Approximately 90 different products are derived from corn, among which grits, corn meal, hominy, oil, starch, amylose, amylopectin, zein, and fibers are worth mentioning for their economic importance. The use of degerminated and ground grain for the production of "fast-food" in the form of extruded foods, commonly known as "snacks", is a major application of corn in the food industry (Gonçalves et al. 2003).

The corn-processing companies that exploit the specialty market have only five white maize cultivars available for grit production (hybrids IPR 119 and IPR 127 and varieties AL Bianco, BR 451 and RS 21). In addition, no studies are available in the literature would provide a theoretical framework of the estimation of genetic parameters, especially for economically relevant traits, e.g., grit production.

The so-called "canjica" is the corn grain or part of it, with partial or total absence of germ resulting from a scraping process, degermination (Castro et al. 2009). In this process, the grain is broken and divided into endosperm, germ and pericarp.

In Brazil, degermination is known as a semi-wet process, in which the corn grain is immersed in hot water and steam is injected. Thus, maize degermination without endosperm disintegration results in higher grit quality. The process can also occur without moistening the grain, using a corn degerminator.

After degermination, the corn grits can be grouped in size classes classified according to the abrasion intensity or for degermination, in subgroups (unpolished; polished), according to color classes (yellow, white or mixed) or for the levels of impurities. If the defect percentage exceeds the maximum tolerance limits, the grains should be classified as below standard, or disqualified when unfit for human or animal consumption.

The purpose of this study is to promote the use of maize as corn grits, by making new cultivars available on the market. The breeding program was initiated with the evaluation of the germplasm by diallel crosses among eight parents from adapted genotypes (commercial hybrids). The

\footnotetext{
${ }^{1}$ Universidade Estadual de Maringá (UEM), Departamento de Agronomia, 87.020-900, Maringá, PR, Brazil. *E-mail: lrscamacho@gmail.com

${ }^{2}$ Universidade Estadual do Norte Fluminense Darcy Ribeiro (UENF), Laboratório de Melhoramento Genético Vegetal, Centro de Ciências e Tecnologias Agropecuárias, 28.013-600, Campos dos Goytacazes, RJ, Brazil
} 
general and specific combining abilities were estimated by the methodology of Griffing (1956), as well as heterosis parameters by the methodology of Gardner and Eberhart (1966). The magnitude of inbreeding depression of the parents was estimated by the methodology of Gardner (1965), and the mean of the possible sets of lines that can be developed from these parents $(\hat{u}+\hat{a})$, as proposed by Vencovsky and Barriga (1992).

\section{MATERIAL AND METHODS}

The crosses to obtain the hybrid combinations were performed in the second growing season of 2009. The experimental evaluations of the parents, the hybrids and their selfings were performed on the Experimental Farm of Iguatemi - FEI (lat $23^{\circ} 25^{\prime} \mathrm{S}$, long $51^{\circ} 57^{\prime} \mathrm{W}$, alt $510 \mathrm{~m}$ asl), in Maringá (PR), in the growing seasons 2009/2010 and $2010 / 2011$.

The experiments were designed as complete blocks with randomized treatments and three replications. We evaluated 44 treatments, of which 8 were parents; 28 hybrids obtained by crossing parents in a complete diallel scheme (excluding the reciprocals) and 8 genotypes belonging to the $S_{1}$ generation derived from selfing of the parents used. The description of the eight genotypes used in this study is given in Table 1.

Each experimental unit consisted of two 15-m rows, spaced $0.90 \mathrm{~m}$ apart, and plants spaced $0.20 \mathrm{~m}$ apart, with a total assessed area of $27 \mathrm{~m}^{2}$. Fertilization and management practices were applied according to technical recommendations for corn (Galvão and Miranda 2004).

Grain yield data (YD, in $\mathrm{t} \mathrm{ha}^{-1}$ ) were collected and standardized to $13 \%$ moisture. The percentages of grit yield (GY), small grit yield (SY) and bran residue (BY) were obtained according to the procedure proposed by Gonçalves (2003).

For grit yield, a clean sample of $10 \mathrm{~kg}$ corn grain per plot was prepared. Each sample was placed in a drum type gritting processor for a pre-set period of 22 seconds per kilogram of sample, at a rotation of $600 \mathrm{rpm}$ of the knive blades of the degerminador. After abrasion, the resulting material was separated into grits and bran using a Tyler 5 sieve. The grits were manually extracted from the bran in a 4 mesh sieve (openings $5.54 \mathrm{~mm}$, wire 21 to $0.81 \mathrm{~mm}$ ). Soon after the sample had been passed through the gritting processor, the fractions grits (canjica, fraction corresponding to the endosperm), small grits and germ (embryo) were weighed.

From the measured traits, individual analysis of variance was performed with treatment partitioning as follows: parents, $F_{1}$ hybrid combinations, $S_{1}$ generations, and the contrasts $F_{1}$ hybrids vs parents and parents $+F_{1}$ hybrids vs $\mathrm{S}_{1}$ generations.

The analysis of variance for traits as affected by the environments was carried out considering the genotype and environment effects as fixed, by the mathematical model:

$$
Y_{i j k}=\mu+G_{i}+E_{j}+G E_{i j}+R / E_{j k}+\varepsilon_{i j k}
$$

where: $Y_{i j k}$ is the observation of variable $Y$ in the $\mathrm{k}^{\text {th }}$ block of the $\mathrm{i}^{\text {th }}$ treatment in the $\mathrm{j}^{\text {th }}$ environment; $\mu$ is the general mean; $G_{i}$ is the effect of the $\mathrm{i}^{\text {th }}$ treatment with $\mathrm{i}=1,2, \ldots$, $\mathrm{g} ; E_{j}$ is the effect of the $\mathrm{j}^{\text {th }}$ environment, with $\mathrm{j}=1,2, \ldots$, e $G E_{i j}$ is the interaction effect of the $\mathrm{i}^{\text {th }}$ treatment with the $\mathrm{j}^{\text {th }}$ environment; $R / E_{j k}$ is the effect of the $\mathrm{k}^{\text {th }}$ block within the $\mathrm{j}^{\text {th }}$ environment, with $\mathrm{k}=1,2, \ldots, \mathrm{r}$; and $\varepsilon_{i j k}$ is the random error associated with observation $Y_{i j k}$.

The partitioning of treatment of the treatment $\mathrm{x}$ environment interaction was performed as follows: parents $\mathrm{x}$ environment, $\mathrm{F}_{1}$ hybrid combinations $\mathrm{x}$ environments, $\mathrm{S}_{1}$ generations $x$ environments, and the contrasts $\left[F_{1}\right.$ hybrid combinations vs parents] $\mathrm{x}$ environment and [parents + $\mathrm{F}_{1}$ hybrids vs $\mathrm{S}_{1}$ generations] $\mathrm{x}$ environment. Means were compared by the Scott-Knott test at 5\% probability.

Combined diallel analyses were performed using method 2 (parents and $\mathrm{F}_{1}$ ) of Griffing (1956) and by the method of Gardner and Eberhart (1966), developed for the analysis of

Table 1. Description of parents used in a complete white maize diallel

\begin{tabular}{lccccc}
\hline Nr. & Cultivars & Institution & Genetics & Cycle & Grain type \\
\hline 1 & IPR 119 & IAPAR & DH & Early & Early \\
2 & IPR 127 & IAPAR & SH & Semi-flint & Fédio \\
3 & IAC Nelore & IAC & FH & Flint \\
4 & HT 932 & IAPAR & DH & Unnown & Semi-flint \\
5 & HD 332 & IAPAR & TH & Unknown & Semi-flint \\
6 & IAPAR 9332 & IAPAR & TH & Unknown & Semi-flint \\
7 & HT 5392 & IAPAR & TH & Unknown & Semi-flint \\
\hline
\end{tabular}

IH: intervarietal hybrid; DH: double-cross hybrid; TH: triple-cross hybrid; SH: single-cross hybrid 
heterosis parameters, both adapted by Cruz et al. (2012). The methodology proposed by Gardner and Eberhart (1966) details the interpretation of the potential per se of the varieties and their hybrids, from the estimation of the variety effect and the partitioning of the total heterosis in mean heterosis, varietal and specific heterosis effects.

The inbreeding depression percentage of the parents was estimated by the method proposed by Gardner (1965) and the mean of the possible sets of lines that can be bred from these parents $(\hat{u}+\hat{a})$, according to Vencovsky and Barriga (1992).

Genetic analysis was performed using the software package Genes (Cruz 2006).

\section{RESULTS AND DISCUSSION}

The parent effect was significant $(\mathrm{p}<0.05)$ for YD (Table 2 ), indicating phenotypic variability in yield between the parents. For the $\mathrm{F}_{1}$ hybrids, only $\mathrm{SY}$ and YD had significant effects. There was no significant interaction between parents and environments, nor between hybrids and environments. Thus, the genotype performance in crop cultivation did not differ, allowing the selection of the best genotypes based on the annual means.

The effect of $\mathrm{S}_{1}$ generations was not significant for the variables (Table 2), indicating no differential effect on the studied genotypes for these traits. However, for GY and SY, the significance of the interaction between $\mathrm{S}_{1}$ generations and environments showed a different behavior of genotypes in the two seasons.

The absence of significant contrast between parent and $\mathrm{F}_{1}$ combinations (Table 2) indicated that the mean hybrid behavior was not different from the mean behavior of the parent, raising doubts about the feasibility of breeding modern hybrids with high performance in the desirable industrial traits. However, it was noted that the significance of interaction between parents versus $F_{1}$ and environments for YD indicated that the difference in yield performance between parents and $\mathrm{F}_{1}$ combinations may vary according to the growing season.

Resende and Duarte (2007) used selective accuracy $\left(\hat{r}_{\hat{g} g}\right)$ as a parameter to assess the quality of cultivar evaluation experiments. According to the same authors, the estimated values of selective accuracy for GY and YD could be classified in the category of high experimental precision, while the estimated values for SY and BY fall into the category of moderate accuracy (Table 2).

In the $\mathrm{S}_{1}$ generation in both years, the mean $\mathrm{YD}$ of the genotypes was lowest (Table 3), due to the manifestation

Table 2. Combined analysis of variance for the traits grit yield (GY), small grit yield (SY), bran yield (BY) and grain yield data (YD), in $28 \mathrm{~F}_{1}$ hybrid combinations, 8 parents and $8 \mathrm{~S}_{1}$ generation genotypes derived from selfings of the parents used

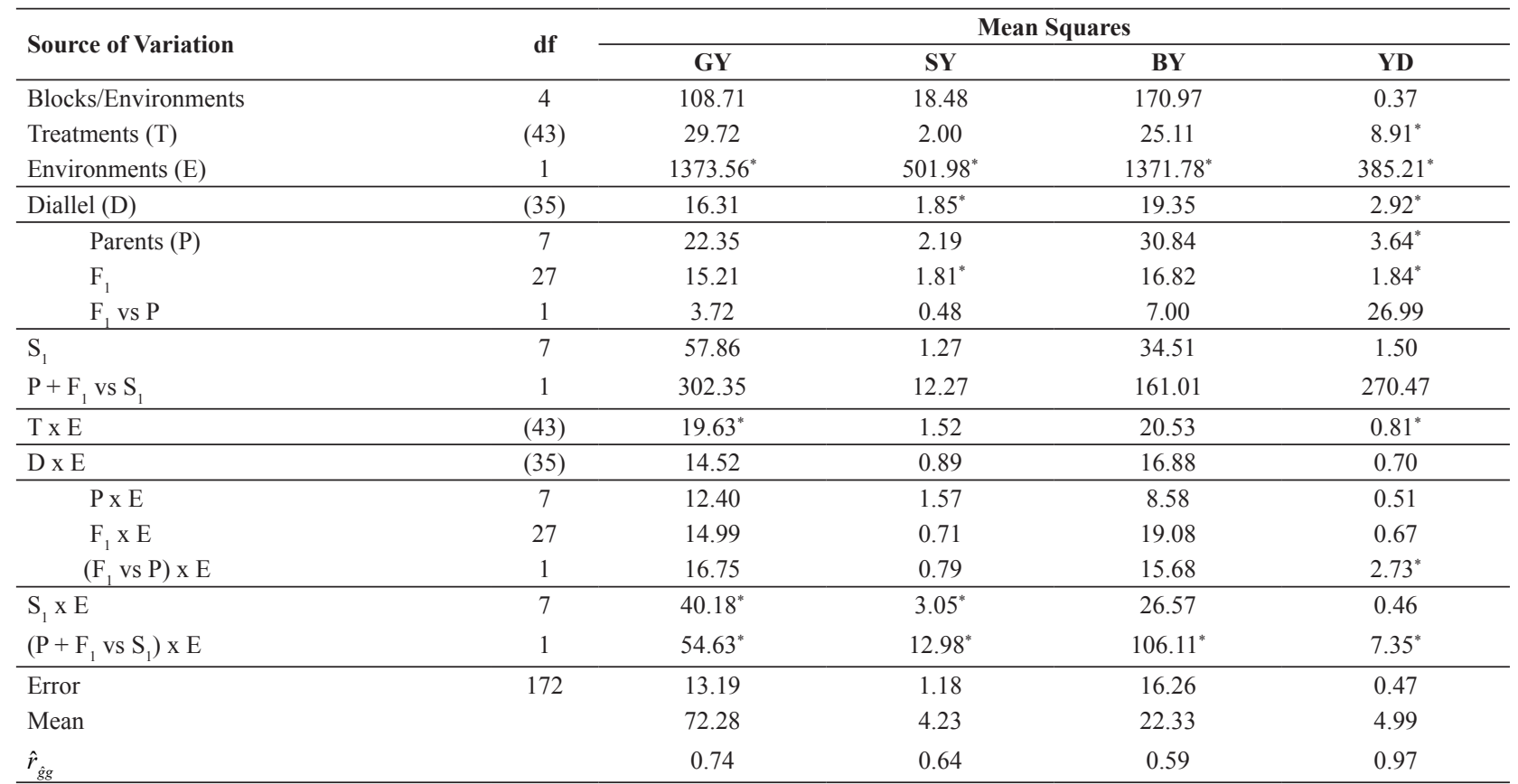

Mean square of variables: grain yield (YD t ha $\left.{ }^{-1}\right)$; grits yield (GY \%); small grit yield (SY \%) and bran yield (BY \%).

${ }^{*}$ significant at $5 \%$ probability. 
of the effects of deleterious alleles caused by inbreeding. A hybrid combination that stood out from the others for GY in the second year was IAC Nelore x HT 932, whereas in the first year there were no outstanding combinations.
The absence of heterotic significance for the traits GY, SY and BY (Table 4) allowed the conclusion that the dominance effects were not relevant for the gene expression of these traits. However for YD, the participation of these

Table 3. Means for grit yield (GY) and grain yield data (YD) of the experiment concerning the complete diallel white corn, and the generation of selfing $\mathrm{S}_{1}$ of the parents

\begin{tabular}{|c|c|c|c|c|c|c|c|}
\hline Generation & Treatment & $\begin{array}{c}\text { Growing } \\
\text { season }\end{array}$ & GY (\%) & YD $\left(\mathrm{t} \mathrm{ha}^{-1}\right)$ & $\begin{array}{c}\text { Growing } \\
\text { season }\end{array}$ & GY (\%) & YD $\left(\mathrm{tha}^{-1}\right)$ \\
\hline$P$ & 2:IPR 127 & 1 & $74.07 \mathrm{C}$ & $2.94 \mathrm{~B}$ & 2 & $73.19 \mathrm{D}$ & $7.15 \mathrm{~A}$ \\
\hline $\mathrm{P}$ & 4:HT 932 & 1 & $71.98 \mathrm{D}$ & $4.99 \mathrm{~A}$ & 2 & $71.04 \mathrm{E}$ & $7.52 \mathrm{~A}$ \\
\hline$P$ & 5:HD 332 & 1 & $68.59 \mathrm{~F}$ & $5.58 \mathrm{~A}$ & 2 & $69.10 \mathrm{~F}$ & $8.75 \mathrm{~A}$ \\
\hline $\mathrm{P}$ & 6:HT 9332 & 1 & $67.98 \mathrm{G}$ & $5.52 \mathrm{~A}$ & 2 & $74.60 \mathrm{C}$ & $8.19 \mathrm{~A}$ \\
\hline $\mathrm{P}$ & 8:HT 392 & 1 & $68.58 \mathrm{~F}$ & $4.24 \mathrm{~A}$ & 2 & $74.65 \mathrm{C}$ & $6.82 \mathrm{~A}$ \\
\hline $\mathrm{S}_{1}$ & 9:IPR 119 & 1 & $68.14 \mathrm{G}$ & $1.81 \mathrm{~B}$ & 2 & $77.86 \mathrm{~B}$ & $2.85 \mathrm{~B}$ \\
\hline $\mathrm{S}_{1}$ & 10:IPR 127 & 1 & $82.39 \mathrm{~A}$ & $1.08 \mathrm{~B}$ & 2 & $72.54 \mathrm{D}$ & $2.72 \mathrm{~B}$ \\
\hline $\mathrm{S}_{1}$ & 11:IAC Nelore & 1 & $73.75 \mathrm{C}$ & $2.35 \mathrm{~B}$ & 2 & $72.40 \mathrm{D}$ & $4.05 \mathrm{~B}$ \\
\hline $\mathrm{S}_{1}$ & 12:HT 932 & 1 & $77.67 \mathrm{~B}$ & $1.41 \mathrm{~B}$ & 2 & $74.37 \mathrm{C}$ & $4.36 \mathrm{~B}$ \\
\hline $\mathrm{F}_{1}$ & $17:(1.2)$ & 1 & $70.88 \mathrm{E}$ & $3.53 \mathrm{~A}$ & 2 & $77.05 \mathrm{~B}$ & $6.45 \mathrm{~A}$ \\
\hline $\mathrm{F}_{1}$ & $18:(1.3)$ & 1 & $65.21 \mathrm{H}$ & $3.81 \mathrm{~A}$ & 2 & $70.85 \mathrm{E}$ & $8.41 \mathrm{~A}$ \\
\hline $\mathrm{F}_{1}$ & $19:(1.4)$ & 1 & $67.83 \mathrm{G}$ & $4.19 \mathrm{~A}$ & 2 & $71.16 \mathrm{E}$ & $6.53 \mathrm{~A}$ \\
\hline $\mathrm{F}_{1}$ & $20:(1.5)$ & 1 & $69.38 \mathrm{E}$ & $3.24 \mathrm{~B}$ & 2 & $72.64 \mathrm{D}$ & $5.98 \mathrm{~A}$ \\
\hline $\mathrm{F}_{1}$ & $21:(1.6)$ & 1 & $70.75 \mathrm{E}$ & $3.83 \mathrm{~A}$ & 2 & $75.53 \mathrm{C}$ & $6.76 \mathrm{~A}$ \\
\hline $\mathrm{F}_{1}$ & $22:(1.7)$ & 1 & $67.01 \mathrm{G}$ & $3.19 \mathrm{~B}$ & 2 & $75.28 \mathrm{C}$ & $5.16 \mathrm{~B}$ \\
\hline $\mathrm{F}_{1}$ & $23:(1.8)$ & 1 & $66.76 \mathrm{G}$ & $4.65 \mathrm{~A}$ & 2 & $72.71 \mathrm{D}$ & $5.87 \mathrm{~A}$ \\
\hline $\mathrm{F}_{1}$ & $24:(2.3)$ & 1 & $68.98 \mathrm{~F}$ & $3.67 \mathrm{~A}$ & 2 & $74.09 \mathrm{C}$ & $6.04 \mathrm{~A}$ \\
\hline $\mathrm{F}_{1}$ & $25:(2.4)$ & 1 & $72.40 \mathrm{D}$ & $3.29 \mathrm{~B}$ & 2 & $78.38 \mathrm{~B}$ & $6.25 \mathrm{~A}$ \\
\hline $\mathrm{F}_{1}$ & $26:(2.5)$ & 1 & $69.66 \mathrm{E}$ & $4.03 \mathrm{~A}$ & 2 & $69.32 \mathrm{~F}$ & $6.12 \mathrm{~A}$ \\
\hline $\mathrm{F}_{1}$ & $33:(3.7)$ & 1 & $68.07 \mathrm{G}$ & $4.26 \mathrm{~A}$ & 2 & $75.46 \mathrm{C}$ & $7.47 \mathrm{~A}$ \\
\hline $\mathrm{F}_{1}$ & $34:(3.8)$ & 1 & $67.96 \mathrm{G}$ & $4.52 \mathrm{~A}$ & 2 & $72.60 \mathrm{D}$ & $7.17 \mathrm{~A}$ \\
\hline $\mathrm{F}_{1}$ & $35:(4.5)$ & 1 & $70.15 \mathrm{E}$ & $3.50 \mathrm{~A}$ & 2 & $75.49 \mathrm{C}$ & $6.40 \mathrm{~A}$ \\
\hline $\mathrm{F}_{1}$ & $36:(4.6)$ & 1 & $67.87 \mathrm{G}$ & $4.22 \mathrm{~A}$ & 2 & $75.39 \mathrm{C}$ & $5.50 \mathrm{~A}$ \\
\hline $\mathrm{F}_{1}$ & $37:(4.7)$ & 1 & $68.72 \mathrm{~F}$ & $3.80 \mathrm{~A}$ & 2 & $72.06 \mathrm{D}$ & $6.69 \mathrm{~A}$ \\
\hline $\mathrm{F}_{1}$ & $38:(4.8)$ & 1 & 71.94 D & $3.20 \mathrm{~B}$ & 2 & $73.83 \mathrm{C}$ & $5.34 \mathrm{~B}$ \\
\hline $\mathrm{F}_{1}$ & $39:(5.6)$ & 1 & $70.51 \mathrm{E}$ & $4.14 \mathrm{~A}$ & 2 & $71.40 \mathrm{E}$ & $5.78 \mathrm{~A}$ \\
\hline $\mathrm{F}_{1}$ & $40:(5.7)$ & 1 & $66.46 \mathrm{H}$ & $4.57 \mathrm{~A}$ & 2 & $70.82 \mathrm{E}$ & $7.12 \mathrm{~A}$ \\
\hline $\mathrm{F}_{1}$ & $41:(5.8)$ & 1 & $68.48 \mathrm{~F}$ & $4.05 \mathrm{~A}$ & 2 & $75.28 \mathrm{C}$ & $6.54 \mathrm{~A}$ \\
\hline $\mathrm{F}_{1}$ & $42:(6.7)$ & 1 & $65.66 \mathrm{H}$ & $4.27 \mathrm{~A}$ & 2 & $72.06 \mathrm{D}$ & $6.33 \mathrm{~A}$ \\
\hline $\mathrm{F}_{1}$ & $43:(6.8)$ & 1 & $68.65 \mathrm{~F}$ & $4.76 \mathrm{~A}$ & 2 & $73.76 \mathrm{C}$ & $7.01 \mathrm{~A}$ \\
\hline $\mathrm{F}_{1}$ & $44:(7.8)$ & 1 & $64.96 \mathrm{H}$ & $4.98 \mathrm{~A}$ & 2 & $76.38 \mathrm{C}$ & $7.31 \mathrm{~A}$ \\
\hline
\end{tabular}

Means followed by the same letters belong to the same group, according to the clustering criterion of Scott-Knott, at $5 \%$ probability. 
effects in the trait expression was evident.

The effect of varieties was significant for all traits (Table 4), allowing the conclusion that additive effects were important in trait expression. The interaction of the variety with environment effect was non-significant for all traits, indicating that the effect can be evaluated based on the annual means.

The significance of variety heterosis and specific heterosis for YD only (Table 4) indicated that the parents did not differ in their respective mean gene frequencies and had the same dispersion of gene frequencies for GY, SY and BY. Moreover, the significance of specific heterosis effects on YD indicated high frequencies of gene loci with dominance of the parents.

The parents IPR 127 and HT 932 were mainly responsible for the increase in GY, based on their estimates of variety effect $\left(\hat{v}_{j}\right)$ (Table 5), resulting in negative $\hat{v}_{j}$ estimates for $\mathrm{SY}$ and BY, which is desirable. Thus, both parents can be recommended to increase the corn gritting ability.

The YD data indicated the possibility of selection of superior parents, both for breeding of lines (based on $\hat{v}_{j}$ ) as well as for crosses, exploiting the heterotic effect of the parent $(\hat{h})$. We recommend the parents HT 5392, IAC Nelore, HT 9332, and HD 332 to breed lines with high YD (Table 5). If the target is the development of hybrid from these parents, the genotypes IPR 127, HT 392 and IAC Nelore become the most recommendable, in view of their positive $\hat{h}_{j}$ values. However, considering simultaneous gains in canjica and grain yield, no parents could be identified that would meet this condition perfectly for line breeding. For crosses and hybrids from the parents, based on $\hat{h}_{i}$, parent IAC Nelore can be recommended, due to the high variety heterosis.

The results of the combined diallel analysis according to the Griffing's Method 2, model I (fixed effects) (1956) are in Table 4, showing that the GCA effects were only significant for SY and YD $(\mathrm{p}<0.05)$, while the SCA effects were significant only for YD. No statistical significance was detected for any interactions between GCA and SCA estimates and the environmental effect (growing seasons). Therefore, the analysis of significant estimates was carried out on the basis of biannual means. The quadratic components indicated a predominance of non-additive over additive effects for YD.

A longer period of time is probably required to efficiently define the predominance of gene effects on the inheritance of the variables GY, SY and BY. Thus, a greater number of years of experimentation would be necessary, although these traits are potentially highly correlated with YD. One possible improvement strategy would be to breed superior

Table 4. Analysis of variance of grit yield (GY), small grit yield (SY), bran yield (BY) and grain yield data (YD), in $28 \mathrm{~F}_{1}$ and 8 white maize hybrids, according diallel analysis

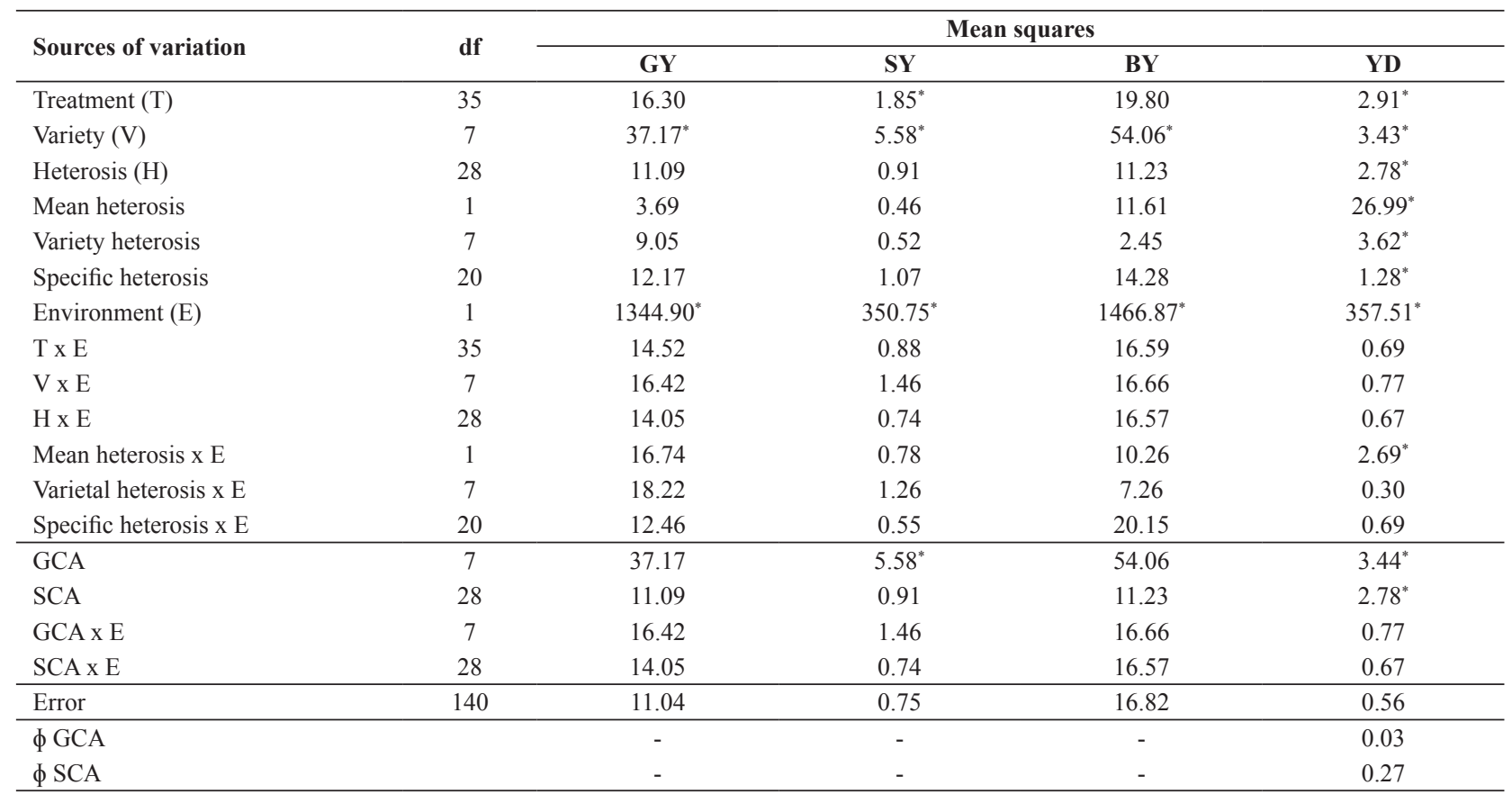

Mean square of the variables: grain yield data (YD t ha $\left.{ }^{-1}\right)$; grit yield (GY \%); small grit yield (SY \%) and bran yield (BY \%).

* Significant by the $\mathrm{F}$ test at $5 \%$ probability. 
lines for subsequent crosses and analysis of the resulting hybrids, so that the lines should be derived from hybrids with parents with high $\hat{v}_{j}$, of which at least one has a relatively high GCA. In addition, it is important that these hybrids have a high $\hat{h}_{j}$ and large deviation from the mean expected for this trait.

The parents with estimates of positive effects of GCA $\left(\hat{g}_{j}\right)$ for YD were HD 332, HT 9332, HT 5392, and IAC Nelore (Table 5). The latter two seem the most suitable for intrapopulational breeding programs, for having a higher concentration of alleles with additive effects (Cruz et al. 2012).

According to Cruz et al. (2012), the most promising hybrid combinations must be selected by the most favorable $\hat{s}_{\mathrm{i} j}$ estimates for the trait in question, but with at least one parent that has superior effects of GCA. Thus, the hybrid combinations HT 9332 x HT 392 (0.278), IAC Nelore x HT 9332 (0.315), IAC Nelore x HT 932 (0.323), and IPR $119 \times$ IAC Nelore (0.573) are the most recommended for reciprocal recurrent selection programs targeting higher $\mathrm{YD}$, in which one parent $\mathrm{A}$ acts as the tester of a population $\mathrm{B}$, so that genotypes with a significant genetic complementation of each other are selected.

For trait SY, parents with negative $\hat{g}_{j}$ estimates were HT 932, IAC Nelore and IPR 127 (Table 5), recommended for a reduction in $\mathrm{SY}$ in intrapopulational breeding programs.

In the mean, all estimates of inbreeding depression (ID) for YD and BY were positive. This indicated that the

Table 5. Estimates of variety effect ( $\hat{v}$ ) for grit yield (GY), small grit yield (SY), bran yield (BY) and grain yield data (YD) and the varietal heterosis effect $\left(\hat{h}_{j}\right)$ for grain yield (YD), and the general combining ability $\left(\hat{g}_{j}\right)$ for the traits SY and YD

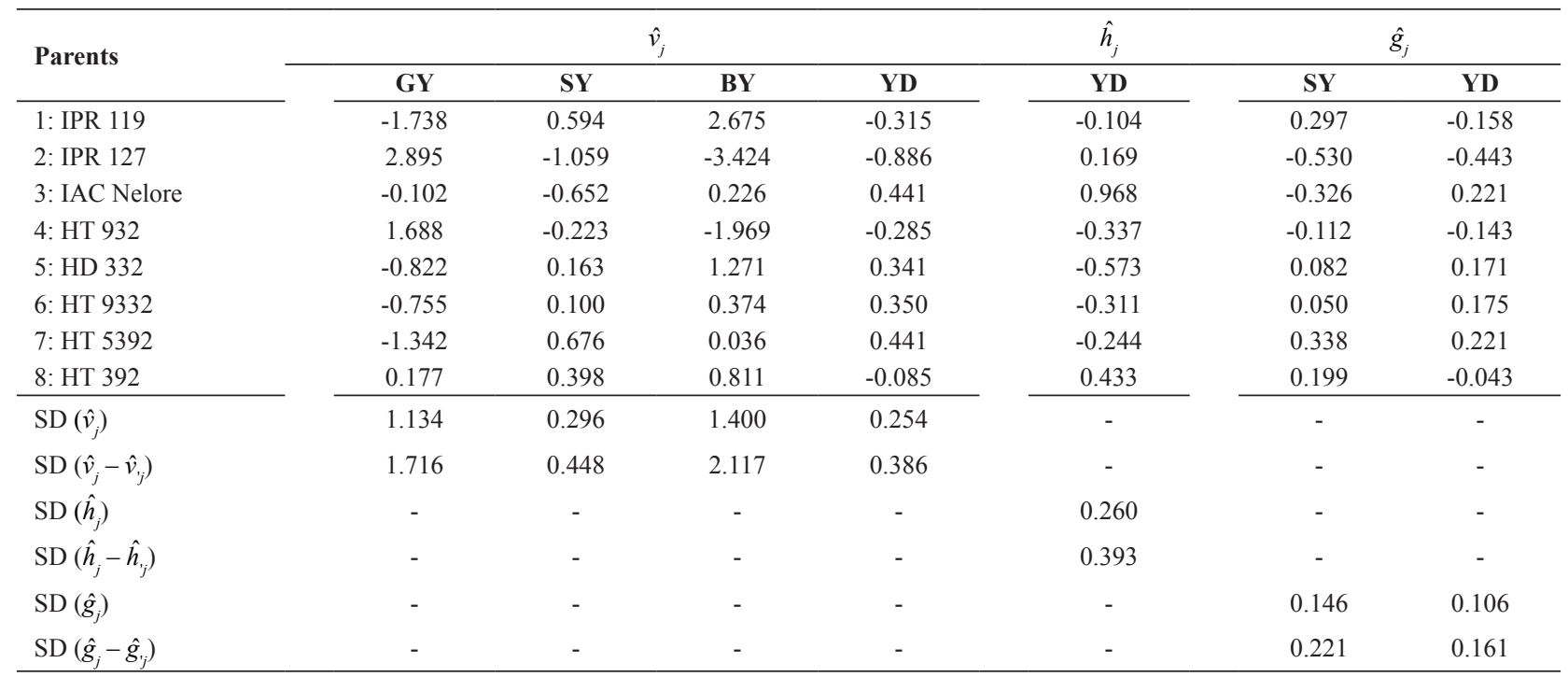

SD: standard deviation.

Table 6. Estimates of inbreeding depression (ID), in percentage, and the potential of hybrids as sources of inbred lines $(\hat{u}+\hat{a})$ for the genotypes used in diallel crosses, in each growing season, for grit yield (GY) and small grit yield (SY), and the mean of both growing seasons for bran yield (BY) and grain yield (YD)

\begin{tabular}{|c|c|c|c|c|c|c|c|c|c|c|c|c|}
\hline \multirow[b]{3}{*}{ Genotypes } & \multicolumn{4}{|c|}{ Growing season $1(2009 / 2010)$} & \multicolumn{4}{|c|}{ Growing season $2(2010 / 2011)$} & \multicolumn{4}{|c|}{ Mean of both growing seasons } \\
\hline & \multicolumn{2}{|c|}{ GY } & \multicolumn{2}{|c|}{ SY } & \multicolumn{2}{|c|}{ GY } & \multicolumn{2}{|c|}{ SY } & \multicolumn{2}{|c|}{ BY } & \multicolumn{2}{|c|}{ YD } \\
\hline & ID & $\hat{u}+\hat{a}$ & ID & $\hat{u}+\hat{a}$ & ID & $\hat{u}+\hat{a}$ & ID & $\hat{u}+\hat{a}$ & ID & $\hat{u}+\hat{a}$ & ID & $\hat{u}+\hat{a}$ \\
\hline IPR 119 & -5.35 & 71.90 & -8.37 & 7.61 & -9.29 & 85.76 & 13.79 & 1.94 & 16.68 & 17.34 & 60.74 & -1.28 \\
\hline IPR 127 & -11.28 & 91.21 & -24.92 & 6.77 & -0.13 & 77.01 & -47.03 & 4.19 & 16.36 & 12.59 & 62.29 & -1.24 \\
\hline IAC Nelore & -5.15 & 77.65 & -135.85 & 13.63 & -1.57 & 74.49 & 0.24 & 2.53 & 15.24 & 16.52 & 40.87 & 0.99 \\
\hline HT 932 & -7.92 & 83.73 & -9.21 & 5.57 & -10.04 & 85.17 & 6.72 & 2.59 & 9.24 & 17.02 & 53.89 & -0.49 \\
\hline HD 332 & -0.99 & 70.43 & -39.44 & 8.42 & 3.81 & 67.27 & 10.23 & 2.44 & 7.55 & 20.94 & 60.41 & -1.49 \\
\hline HT 9332 & -3.16 & 72.70 & -5.00 & 6.70 & -4.70 & 80.81 & -15.86 & 3.43 & 6.67 & 20.38 & 50.51 & -0.07 \\
\hline HT 5392 & -3.33 & 72.51 & 11.61 & 4.86 & -1.25 & 75.93 & -7.83 & 3.82 & 2.91 & 21.86 & 54.85 & -0.67 \\
\hline HT 392 & -4.49 & 75.20 & -42.51 & 9.42 & -2.95 & 79.42 & 30.47 & 1.44 & 7.76 & 19.91 & 43.05 & 0.77 \\
\hline
\end{tabular}

Negative values: superiority of $\mathrm{S}_{1}$ generations; positive values: superiority of parents. 
means tend to decrease over the selfing generations, which is expected due to the expression of effects of deleterious alleles caused by inbreeding.

With regard to $\mathrm{YD}$, the annual means of the percentage of ID in each parent ranged from 40.87 (IAC Nelore) to $62.29 \%$ (IPR 127) (Table 6). The differences between the ID values of the parents were relatively modest, most likely because the genotypes studied had already undergone one or more selection cycles.

The lowest ID value for YD was found for the intervarietal hybrid IAC Nelore (Table 6). Due to its genetic structure, this genotype has greater yield stability, increasing expectations of the possibility of breeding of lines with high frequency of favorable alleles. For YD, the results of $(\hat{u}+\hat{a})$ also show that higher-yielding lines could be bred from IAC Nelore, due to the higher frequency of favorable alleles. The negative estimates of $(\hat{u}+\hat{a})$ may result from estimation errors contained in $(\hat{u}+\hat{a})$ or from limitations of the genetic model, insofar as it disregards epistatic effects (Vencovsky and Barriga 1992). To obtain results with positive values, it was inferred that ID should not exceed $50 \%$ after only one selfing.

With the estimates of $(\hat{u}+\hat{a})$ of the first year, the parents most recommended for breeding of lines with high GY were IPR 127 and HT 932. In the second year, IPR 119 and HT 932 stood out. For trait SY, the parents most recommended for breeding of lines with low SY in the first year were HT 932 and HT 5392, and in the second year, IPR 119 and HT 392. The lines with lowest BY would be bred from the parents IPR 127, IAC Nelore and HT 932.

Although predominance of additive effects for the studied industrial traits and of non- additive effects for YD seems likely, further studies will be required to check the possibility of increased corn gritting ability, especially with regard to its relationship with YD over several years.

\section{Avaliação da capacidade combinatória de milho branco para canjica}

Resumo - Com o objetivo de avaliar o potencial genético de milho branco para canjica, foram avaliados 28 híbridos resultantes de cruzamentos dialélicos entre oito genitores, incluindo os parentais e as gerações $S_{1}$. Foram estimadas as capacidades combinatórias e os níveis de heterose e depressão endogâmica. Os genitores utilizados foram os principais híbridos de milho branco pertencentes ao germoplasma brasileiro. As combinações HT 9332 x HT 392, IAC Nelore x HT 9332, IAC Nelore x HT 932 e IPR $119 x$ IAC Nelore são promissoras para programas de seleção recorrente recíproca para maior rendimento de grãos. O híbrido IPR 127 foi indicado como fonte de linhagens com características industriais favoráveis ao canjicamento. O híbrido IAC Nelore apresentou a menor estimativa de depressão por endogamia e foi recomendado para a extração de linhagens e participação em híbridos e compostos mais produtivos.

Palavras-chave: Zea mays L., heterose, rendimento de canjica.

\section{REFERENCES}

Castro MVL, Naves MMV, Oliveira JP and Oliveira Froes L (2009) Rendimento industrial e composição química de milho de alta qualidade proteica em relação a híbridos comerciais. Pesquisa Agropecuária Tropical 39: 233-242.

Cruz CD (2006) Programa Genes: Biometria. Editora UFV, Viçosa, 382p.

Cruz CD, Regazzi AJ and Carneiro PCS (2012) Modelos biométricos aplicados ao melhoramento genético. Editora UFV, Viçosa, 514p.

Galvão JCC and Miranda GV (2004) Tecnologias de produção de milho. Editora UFV, Viçosa, 366p.

Gardner CO (1965) Teoria de genética estadística aplicable as las medias de variedades, sus cruces y poblaciones afines. Fitotecnica Latinoamericana 2: 11-22.
Gardner CO and Eberhart SA (1966) Analysis and interpretation of the variety cross diallel and related populations. Biometrics 22: 439-452.

Gonçalves RA, Santos JP, Tomé PHF; Pereira RGFA, Ascheri JLR and Abreu CMP (2003) Yield and chemical composition of corn cultivate in dry-milling and grit production. Ciência e Agrotecnologia 27: 643-650.

Griffing B (1956) Concept of general and specific combining ability in relation to diallel crossing systems. Australian Journal Biology Science 9: 463-493.

Resende MDV and Duarte JB (2007) Precisão e controle de qualidade em experimentos de avaliação de cultivares. Pesquisa Agropecuária Tropical 37: 182-194.

Vencovsky R and Barriga P (1992) Genética biométrica no fitomelhoramento. Revista Brasileira de Genética, Ribeirão Preto, 496p. 